\title{
FEATURES OF MECHANICAL INJURIES OF THE LOWER EXTREMITIES ACCORDING TO A FORENSIC MEDICAL EXAMINATION: A RETROSPECTIVE ANALYSIS
}

DOI: 10.36740/WLek202006121

\author{
Viacheslav K. Sokol' ${ }^{\text {, Kostyantin M. Sokol' }{ }^{1} \text {, Vira A. Kolesnichenko² }}$ \\ 'KHARKIV NATIONAL MEDICAL UNIVERSITY, KHARKIV, UKRAINE \\ ${ }^{2}$ KHARKIV NATIONAL UNIVERSITY NAMED AFTER V.N. KARAZIN, KHARKIV, UKRAINE
}

\begin{abstract}
The aim: To study the structure of lower extremities' mechanical injuries and the reasons for an additional (commission) forensic medical examination appointment, according to a retrospective analysis.

Materials and methods: research protocols were116 reports of additional (commission) forensic medical examinations of victims with mechanical trauma to lower extremities; research methods - retrospective analysis, statistical method. Reports of forensic medical commission examination were selected by random sampling, for the period February - June 2018.

Results: As a result of a retrospective analysis of commission (additional) forensic medical examination, the prevalence of road traffic injuries (109; $94.0 \%$ cases) in mechanical injuries of the lower extremities was established. Domestic $(5 ; 4.2 \%)$, work $(1 ; 0.9 \%)$ and sports $(1 ; 0.9 \%)$ injuries were also indicated It was found that to establish the degree of permanent disability loss according to the outcome of fractures of the femur and shin bones, commission examinations were appointed in $24.1 \%$ of cases. The main reason for the commission examinations appointment was to establish the bodily injuries presence (6.9\%), as well as to establish the bodily injuries presence and their severity (62.9\%) in cases of road traffic injury (lethal and non-lethal).

Conclusions: The use of commission forensic medical examination is mainly related to the criminal law criteria of the preliminary investigation stage. The reason for conducting commission examinations on medical criteria is to establish the outcome of a fracture of the lower limb.
\end{abstract}

KEY WORDS: mechanical trauma of the lower extremities, forensic medical examination, outcomes of fractures of long bones of the lower extremities, road traffic injury

Wiad Lek. 2020;73(6):1189-1193

\section{INTRODUCTION}

An expert assessment of bodily injuries severity to victims with mechanical trauma of lower extremities and an uncomplicated post-traumatic period usually is confined to primary forensic examination. However, in cases when there is a development of post-traumatic arthrosis and/or post-traumatic contractures of the joints, delayed consolidation or non-fusion of bone fragments with the nearthroses formation and a persistent limitation of the bearing and walking functions, an additional forensic medical examination is carried out to determine the disability degree of victims according to the outcome of a mechanical injury. In addition, the tasks of commission examinations are often to establish the fact and mechanism of causing bodily harm, their causal relationship with the circumstances of the injury. Given the fact that the main cause of fractures of the long bones of the lower extremities is a road traffic injury, in some cases, there is a need for a forensic technician commission examination. This situation leads to a prolongation of the investigation period. This situation does not contribute to the principles of inevitability of the criminal process and, in a certain way, it violates the interests of the victims. It should be noted that the nature and frequency of the reasons for the appointment of commission examinations in cases of the lower extremities' mechanical injury have not been studied, although such data are necessary to improve the forensic medical and expert assessment of the severity of bodily injuries in this category of victims.

\section{THE AIM}

Aim of the study - to study the structure of lower extremities' mechanical injuries and the reasons for an additional (commission) forensic medical examination appointment, according to a retrospective analysis.

\section{MATERIALS AND METHODS}

Study material - 116 reports of additional (commission) forensic medical examinations of victims with mechanical trauma to lower extremities. In all cases, an expert assessment was carried out at the Kharkov Regional Bureau of Forensic Medical Examination (KRBFME). Reports of forensic medical commission examination were selected by random sampling, for the period February - June 2018. 
Table I. Distribution of victims due to mechanical injuries of the lower extremities, gender and age

\begin{tabular}{|c|c|c|}
\hline \multirow[t]{2}{*}{ Parameters } & \multicolumn{2}{|c|}{$\begin{array}{l}\text { Number of victims } \\
\quad(n=116)\end{array}$} \\
\hline & abs. & $\%$ \\
\hline Road traffic injuries & 109 & 94,0 \\
\hline \multicolumn{3}{|c|}{ Gender } \\
\hline - male & 96 & 82,8 \\
\hline - female & 13 & 11,2 \\
\hline Average age & \multicolumn{2}{|c|}{$39,7 \pm 12,8 \mathrm{y} / \mathrm{o}$} \\
\hline Domestic injuries & 5 & 4,2 \\
\hline \multicolumn{3}{|c|}{ Gender } \\
\hline - male & 3 & 2.6 \\
\hline - female & 2 & 1.6 \\
\hline Average age & \multicolumn{2}{|c|}{$46,3 \pm 8,5 \mathrm{y} / \mathrm{o}$} \\
\hline Work injuries & 1 & 0,9 \\
\hline \multicolumn{3}{|c|}{ Gender } \\
\hline - male & 1 & 0,9 \\
\hline - female & - & 0,0 \\
\hline Age & \multicolumn{2}{|c|}{$38 \mathrm{y} / \mathrm{o}$} \\
\hline Sports injuries & 1 & 0,9 \\
\hline \multicolumn{3}{|c|}{ Gender } \\
\hline - male & - & 0,0 \\
\hline - female & 1 & 0,9 \\
\hline Age & \multicolumn{2}{|c|}{$29 \mathrm{y} / \mathrm{o}$} \\
\hline
\end{tabular}

Criteria for the inclusion were forensic medical examinations' reports with: (I) victims with isolated mechanical trauma of lower extremities; (II) polytrauma (multiple and combined injuries), in which mechanical injury to the lower extremities was the dominant damage; (III) polytrauma in which mechanical trauma to the lower extremities was not a dominant injury. The study included polytrauma with both fatal and non-fatal outcomes.

Exclusion criteria were primary forensic medical examinations' reports with: mechanical trauma to the lower extremities; reports of forensic medical examinations with thermal, chemical trauma, barotrauma, electric trauma, as well as combined lower limb trauma

There was a prevalence of males ( 100 males; $86.2 \%$ ), the men to women ratio was $6.25: 1$. The average age of the victims was $42.3 \pm 11.2$ years $(10-78$ years).

Research methods - retrospective analysis, statistical method. When conducting a retrospective analysis, the mechanism, nature and location of the injury, as well as the reasons for the forensic medical commission examinations, were investigated.

Data processing performed using descriptive statistics.

\section{RESULTS}

As for circumstances of mechanical injuries of the lower extremities, road traffic injuries prevailed - 109 (94.0\%) cases. Domestic $(5 ; 4.2 \%)$, work $(1 ; 0.9 \%)$ and sports (1; $0.9 \%$ ) injuries were also indicated (Table 1).

The gender distribution and average age of victims of road traffic injuries and domestic injuries differed from similar indicators for the whole group of 116 victims. For the group of road traffic injuries, the men/women ratio reached 7.38:1; in the group of domestic injuries - 1.5:1; as a whole for the group of all victims $-6.25: 1$. The average age in the study groups was $39.7 \pm 12.8$ years; $46.3 \pm 8.5$ years and $42.3 \pm 11.2$ years, respectively (Table I).

A study of the structure of mechanical injuries of the lower extremities of victims of road traffic injuries made it possible to establish the following (the total number of victims in this group, 109 people, was taken as 100\%). Isolated fractures of the femur (3 cases; $2.8 \%$ ) and lower leg bones (12 cases; $11.0 \%$ ), which were not life-threatening, were found mainly among pedestrians when they hit a car at a relatively low speed (in the streets near houses). A collision of a car with a pedestrian, as well as a collision of vehicles on highways, were usually accompanied by polytrauma (multiple skeleton fractures - in 13 cases; $11.9 \%$, combined damage - in 81 cases; $74.3 \%$ ) with a fatal outcome in 40 cases (36.7\%), mainly pedestrians ( 23 cases; $21.1 \%$ ) and drivers (14 cases; $12.8 \%$ ). The dominant injuries that led to the death were injuries to head, chest, abdomen, pelvic organs, which were accompanied by bleeding with the development of terminal stages of traumatic shock. Drivers had almost the same frequency with hip fractures (11 cases; $10.1 \%$ ) and bone fractures in both segments (thigh and lower leg) - 13 cases; $11.9 \%$. Pedestrian trauma was featuring fractures of the femur in combination with lower leg bones' fractures. Passengers of motor vehicles more often had fractures of the femur (7 cases; 6.4\%). For multiple skeletal bone fractures, dominant fractures of the femur and lower leg in pedestrians were characteristic (9 cases; 8.3\%) - Table. II.

A study of the reasons for the appointment of forensic medical commission examinations made it possible to establish the following: the assessment of the permanent disability degree was based on the outcome of a mechanical injury of the lower extremities was carried out in 28 cases $(24.1 \%)$ of road traffic injury, which were not life-threatening, and in a single observation (0.9\%) - of a work injury. Unsatisfactory outcomes of lower extremities long bones' fractures in 15 cases (12.9\%) were associated with the nature of trauma, as the intra- and periarticular fractures of the acetabulum, femur and tibia, which lead to the development of post-traumatic arthrosis of an injured joint, often with persistent post-traumatic contracture. Unsatisfactory outcomes of femur and lower leg bones' fractures (13 cases; $11.2 \%$ ), as well as pelvic fractures with rupture of pubic joint during combined road traffic injury ( 1 case; $0.9 \%$ ) were associated with iatrogenic errors in choosing the method of osteosynthesis, the development of complications in the short period after surgery and inadequate rehabilitation period (table. III).

Most often, forensic medical commission examinations were associated with the establishment of the bodily injury 
Table II. Structure of mechanical injuries of the lower extremities of victims of road traffic injuries

\begin{tabular}{|c|c|c|c|c|c|c|c|}
\hline \multirow{2}{*}{ Parameters } & \multicolumn{2}{|c|}{ Vehicle drivers } & \multicolumn{2}{|c|}{ Vehicle passengers } & \multicolumn{2}{|c|}{ Pedestrians } & \multirow{2}{*}{ Total } \\
\hline & Male & Female & Male & Female & Male & Female & \\
\hline \multicolumn{8}{|c|}{ Isolated fractures of the femur } \\
\hline - proximal part & - & - & - & - & $\begin{array}{c}1 \\
(0.9 \%) \\
\end{array}$ & $\begin{array}{c}1 \\
(0.9 \%) \\
\end{array}$ & $\begin{array}{c}2 \\
(1.8 \%)\end{array}$ \\
\hline - diaphysis (upper third) & - & - & $\begin{array}{c}1 \\
(0.9 \%) \\
\end{array}$ & - & - & - & $\begin{array}{c}1 \\
(0.9 \%) \\
\end{array}$ \\
\hline Isolated shin bones' fractures & - & - & - & - & $\begin{array}{c}9 \\
(8.3 \%) \\
\end{array}$ & $\begin{array}{c}3 \\
(2.8 \%)\end{array}$ & $\begin{array}{c}12 \\
(11.0 \%)\end{array}$ \\
\hline \multicolumn{8}{|c|}{ Polytrauma } \\
\hline - multiple fractures with a prevailing hip fracture & $\begin{array}{c}1 \\
(0.9 \%) \\
\end{array}$ & - & - & - & $\begin{array}{c}2 \\
(1.8 \%) \\
\end{array}$ & - & $\begin{array}{c}3 \\
(2.8 \%) \\
\end{array}$ \\
\hline $\begin{array}{l}\text { - multiple fractures with a prevailing hip fracture and } \\
\text { leg fractures }\end{array}$ & - & - & $\begin{array}{c}1 \\
(0.9 \%)\end{array}$ & - & $\begin{array}{c}6 \\
(5.5 \%) \\
\end{array}$ & $\begin{array}{c}3 \\
(2.8 \%)\end{array}$ & $\begin{array}{c}10 \\
(9.2 \%)\end{array}$ \\
\hline - combined injuries with a prevailing hip fracture & $\begin{array}{c}4 \\
(3.7 \%)\end{array}$ & - & $\begin{array}{c}6 \\
(5.5 \%)\end{array}$ & $\begin{array}{c}1 \\
(0.9 \%)\end{array}$ & $\begin{array}{c}2 \\
(1.8 \%)\end{array}$ & - & $\begin{array}{c}13 \\
(11.9 \%)\end{array}$ \\
\hline - combined injuries with non-prevailing hip fracture & $\begin{array}{c}7 \\
(6.4 \%) \\
\end{array}$ & - & - & - & $\begin{array}{c}2 \\
(1.8 \%) \\
\end{array}$ & & $\begin{array}{c}9 \\
(8.3 \%)\end{array}$ \\
\hline $\begin{array}{l}\text { - combined injuries with non-prevailing hip fracture } \\
\text { and leg fractures }\end{array}$ & $\begin{array}{c}11 \\
(10.1 \%)\end{array}$ & $\begin{array}{c}2 \\
(1.8 \%) \\
\end{array}$ & $\begin{array}{c}3 \\
(2.8 \%)\end{array}$ & - & $\begin{array}{c}39 \\
(35,8 \%)\end{array}$ & $\begin{array}{c}4 \\
(3.7 \%)\end{array}$ & $\begin{array}{c}59 \\
(54,1 \%)\end{array}$ \\
\hline Total & $\begin{array}{c}23 \\
(21.1 \%)\end{array}$ & $\begin{array}{c}2 \\
(1.8 \%) \\
\end{array}$ & $\begin{array}{c}11 \\
(10.1 \%) \\
\end{array}$ & $\begin{array}{c}1 \\
(0.9 \%) \\
\end{array}$ & $\begin{array}{c}61 \\
(56.0 \%) \\
\end{array}$ & $\begin{array}{c}11 \\
(10.1 \%)\end{array}$ & $\begin{array}{c}109 \\
(100 \%) \\
\end{array}$ \\
\hline \multicolumn{8}{|c|}{ Outcomes } \\
\hline - fatal outcome & $\begin{array}{c}12 \\
(11.0 \%) \\
\end{array}$ & $\begin{array}{c}2 \\
(1.8 \%) \\
\end{array}$ & $\begin{array}{c}3 \\
(2.8 \%) \\
\end{array}$ & - & $\begin{array}{c}19 \\
(17.4 \%) \\
\end{array}$ & $\begin{array}{c}4 \\
(3.7 \%) \\
\end{array}$ & $\begin{array}{c}40 \\
(36.7 \%) \\
\end{array}$ \\
\hline - non-lethal outcome & $\begin{array}{c}11 \\
(10.1 \%)\end{array}$ & - & $\begin{array}{c}8 \\
(7.3 \%) \\
\end{array}$ & $\begin{array}{c}1 \\
(0.9 \%) \\
\end{array}$ & $\begin{array}{c}42 \\
(38.5 \%) \\
\end{array}$ & $\begin{array}{c}7 \\
(6.4 \%) \\
\end{array}$ & $\begin{array}{c}69 \\
(63.3 \%) \\
\end{array}$ \\
\hline Total & $\begin{array}{c}23 \\
(21.1 \%)\end{array}$ & $\begin{array}{c}2 \\
(1.8 \%)\end{array}$ & $\begin{array}{c}11 \\
(10.1 \%)\end{array}$ & $\begin{array}{c}1 \\
(0.9 \%)\end{array}$ & $\begin{array}{c}61 \\
(56.0 \%) \\
\end{array}$ & $\begin{array}{c}11 \\
(10.1 \%)\end{array}$ & $\begin{array}{c}109 \\
(100 \%)\end{array}$ \\
\hline
\end{tabular}

presence $(8 ; 6.9 \%)$, as well as with the bodily injury presence and severity establishment $(73 ; 62.9 \%)$ - table. 3 . In 20 (17.2\%) cases, additional forensic technical examinations were required.

Commission examinations were appointed on average in $3.5 \pm 0.3$ months in cases with fatal outcomes of road traffic accidents and on average in $2.7 \pm 0.8$ months in cases with non-fatal outcomes; the duration of examinations reached $2.4 \pm 0.5$ months, and $4.0 \pm 1.0$ months respectively. When appointing forensic medical commission examination, questions that were clarified at the preliminary investigation stage arose while examining the scene of an accident, examining the corpses of people who died as a result of car accidents, examining victims, as well as examining material evidence (in particular, clothing and vehicles in traffic accidents). When conducting these commission examinations, forensic medical experts were not provided with all the necessary information and material evidence. That did not allow to clarify a number of issues regarding the features and location of traces and injuries on the body and clothing; prescription of injuries and their intravital or post-mortem origin; damage formation mechanism (shock, concussion, compression, friction); time of occur- rence of damage; places of traumatic force application and direction of the force.

\section{DISCUSSION}

To date, traffic accidents injuries continue to be one of the most important medical, social and economic problems in the world. According to $\mathrm{WHO}$, although mortality rates relative to the world's population have been stabilized in recent years, deaths from road traffic injuries continue to rise, amounting to 1.35 million deaths per year, and accidents are the leading cause of death for children and young people (5-29 years old) [1]. In Ukraine, in 2019, 160,675 accidents occurred, which amounted to an average of 440 accidents per day. During these accidents, 3,454 people died (10 people per day) and 32,736 people (90 people per day) were injured. Compared to 2018, there is a slight increase in all indicators: the total number of accidents increased by 7.0\% (150 120 accidents), the number of accidents per day - by $7.3 \%$ (411 accidents); the number of deaths - by $3.1 \%$ (3350 people) and the number of injured - by $6.0 \%$ (30884 people) [2].

A WHO report (2018) also noted a different mortality rate among different groups of road users. Globally, pe- 
Table III. Reasons for the appointment of forensic medical examinations for victims with mechanical trauma to the lower extremities

\begin{tabular}{|c|c|c|c|c|c|}
\hline Parameters & $\begin{array}{c}\text { Road traffic } \\
\text { injuries } \\
(n=109)\end{array}$ & $\begin{array}{c}\text { Domestic } \\
\text { injury } \\
(n=5)\end{array}$ & $\begin{array}{l}\text { Work } \\
\text { injury } \\
(n=1)\end{array}$ & $\begin{array}{l}\text { Sports } \\
\text { injury } \\
(n=1)\end{array}$ & $\begin{array}{c}\text { Total } \\
(n=116)\end{array}$ \\
\hline \multicolumn{6}{|c|}{ Adverse outcome of mechanical injury } \\
\hline $\begin{array}{l}\text { - incorrectly fused fractures of the ileum, pubic and ischial } \\
\text { bones, non-fused gap with divergence of the pubic joint }\end{array}$ & $\begin{array}{c}1 \\
0.9 \%\end{array}$ & - & - & - & $\begin{array}{c}1 \\
0.9 \%\end{array}$ \\
\hline - post-traumatic arthrosis and hip contracture & $\begin{array}{c}6 \\
5.2 \%\end{array}$ & - & $\begin{array}{c}1 \\
0.9 \%\end{array}$ & - & $\begin{array}{c}7 \\
6.0 \%\end{array}$ \\
\hline - nonfused femoral fracture & $\begin{array}{l}2 \\
1.6 \%\end{array}$ & - & - & - & $\begin{array}{c}2 \\
1.6 \%\end{array}$ \\
\hline $\begin{array}{l}\text { - abnormally fused fracture with deformation and } \\
\text { shortening of the femur }\end{array}$ & $\begin{array}{c}5 \\
4.2 \%\end{array}$ & - & - & - & $\begin{array}{c}5 \\
4.2 \%\end{array}$ \\
\hline - post-traumatic arthrosis with knee contracture & $\begin{array}{c}6 \\
5.2 \% \\
\end{array}$ & - & - & - & $\begin{array}{c}6 \\
5.2 \% \\
\end{array}$ \\
\hline - nonfused fracture of the tibia & $\begin{array}{c}4 \\
3.4 \%\end{array}$ & - & - & - & $\begin{array}{c}4 \\
3.4 \%\end{array}$ \\
\hline $\begin{array}{l}\text { - incorrectly fused fracture with deformation and } \\
\text { shortening of the tibia }\end{array}$ & $\begin{array}{c}5 \\
4.2 \% \\
\end{array}$ & - & - & - & $\begin{array}{c}5 \\
4.2 \%\end{array}$ \\
\hline Establishment of the fact of bodily injury & $\begin{array}{c}8 \\
6.9 \% \\
\end{array}$ & - & - & - & $\begin{array}{c}8 \\
6.9 \% \\
\end{array}$ \\
\hline $\begin{array}{c}\text { Establishment of the fact of causing and the severity of } \\
\text { bodily harm }\end{array}$ & $\begin{array}{c}73 \\
62.9 \%\end{array}$ & $\begin{array}{c}1 \\
0.9 \%\end{array}$ & - & - & $\begin{array}{c}74 \\
63.8 \%\end{array}$ \\
\hline $\begin{array}{l}\text { Disagreement with the results of the primary forensic } \\
\text { medical examination }\end{array}$ & - & $\begin{array}{c}4 \\
3.4 \%\end{array}$ & - & $\begin{array}{c}1 \\
0.9\end{array}$ & $\begin{array}{l}5 \\
4.2 \%\end{array}$ \\
\hline Total & $\begin{array}{c}109 \\
94.0 \%\end{array}$ & $\begin{array}{c}5 \\
4.2 \%\end{array}$ & $\begin{array}{c}1 \\
0.9 \%\end{array}$ & $\begin{array}{c}1 \\
0.9 \%\end{array}$ & $\begin{array}{c}116 \\
100,0 \%\end{array}$ \\
\hline
\end{tabular}

destrians and cyclists account for $26 \%$ of all road accident deaths, with $44 \%$ in Africa and 36\% in the Eastern Mediterranean. Motorcyclists and their passengers account for $28 \%$ of all deaths due to road accidents, but in some regions this figure is higher - for example, in Southeast Asia it is $43 \%$, and in the Western Pacific - 36\% [WHO]. In the study of Lastovetsky A.G. et al. it is noted that against the general background of an increase in the absolute values of the number of accidents involving pedestrians, a steady decrease in the proportion of this accident type, from the total, from $48.6 \%$ in 2001 to $30 \%$ in 2011 is observed, however, the severity of the consequences of accidents for pedestrians remains the same. The proportion of accidents caused by pedestrians in the total number of accidents decreased from $30.2 \%$ to $12.8 \%$ and is characterized by a decrease in the number of dead pedestrians [3].

One of the characteristic injuries of pedestrians in a collision with a car is bumper fractures of the femur or lower leg bones resulting from the contact of the lower extremities with the bumper of the car. At the same time, the nature of morphological disorders in the tissues of the lower extremities depends on the speed (and, accordingly, kinetic energy) of the moving car. Given the low speed of the vehicle and the lack of support of the lower limb that is in contact with it, a bumper fracture does not occur (up to $10 \%$ of cases) [4]. With an increase in vehicle speed over $60-70 \mathrm{~km} / \mathrm{h}$, a transverse fracture is formed by the shifting mechanism [4]. The direction of the bending of the bone indicates the direction of the traumatic force.

The degree of injury to drivers and passengers of a vehicle depends on the collision mechanism (frontal, side, rear collisions, rollovers, collisions with turning the vehicle in a horizontal axis), size and type of vehicle. Smaller cars are able to absorb less kinetic energy, so if they are involved in an accident, more severe damage occurs and a higher mortality rate is noted. If trucks and sports cars participate in accidents, more accidents occur with only one participant [5].

Due to the design features of modern cars aimed at absorbing and dissipating kinetic energy in a collision of vehicles (energy-absorbing steering columns, seat belts, airbags), a decrease in the frequency of deaths among drivers and passengers to $38 \%[6,7]$. Fastening seatbelts in people sitting in the front seats reduces the risk of fatal injuries by $45 \%$ and non-lethal polytrauma by $50 \%$. At the same time, with high kinetic energy of collision between the driver and the passenger in the front seat, complicated injuries of the cervical spine due to whiplash injury, damage to internal organs, clavicle fractures (in the place of fastening the seat belt) are possible $[8,9]$.

\section{CONCLUSIONS}

A retrospective analysis of the forensic medical examinations of victims with lower extremities' mechanical injuries 
showed that the need for an additional expert assessment of injuries' severity arises in cases of adverse outcomes of fractures of the femur and lower leg bones due to road traffic injury (24.1\%). The main reason for the commission examinations appointment was to establish the bodily injuries presence (6.9\%), as well as to establish the bodily injuries presence and their severity (62.9\%) in cases of road traffic injury (lethal and non-lethal). The lack of an appropriate investigator ordinance at the preliminary investigation stage did not allow experts to conduct the initial forensic medical examination in the needed volume and to give a full expert opinion on the results of the commission examination.

\section{REFERENCES}

1. Global status report on road safety 2018. Geneva: World Health Organization;2018; $424 \mathrm{p}$.

2. Statistika DTP v Ukraini za period z 01.01.2019 po 31.12.2019 [Road accident statistics in Ukraine for the period from 01/01/2019 to 31/12/2019]. http://patrol.police.gov.ua/statystyka/ (Ua)

3. Lastovetsky A.G., Deineko D.A., Lebedev M.V. Viyavlenie nekotorich mechanizmov povrezhdayushcheho faktora pri naezde avtomobilya na peshechoda pri osushchestvlenii sudebno-meditsinskoy ekspertizi [Identifying some mechanisms of damaging factor at auto-pedestrian accident during forensic examination]. Social aspects of public health. 2013;22c. http://vestnik.mednet.ru/content/view/489/30/ (Ru)

4. Isakov V.D. Avtomobilnaya travma: lektsiya dlya slushateley VI fakulteta tsikla «Sudebnaya meditsina» [Car injury: a lecture for students of the VI Faculty of the cycle «Forensic Medicine»]. SPb:VMA; 1996. (Ru)

5. Thais R., Vassallo J.M., Herraiz I. The influence of economic incentives linked to road safety indicators on accidents: The case of toll concessions in Spain." Accident Analysis \& Prevention. 2013;59:529-36.

6. Ordonez Mayana L., Martınez Silvab I., Represas Vazquezc C. et al. Predictive models for the assessment of bodily harm. Forensic sciences research. 2017;Sept;2(4):185-191 https://doi.org/10.1080/2096179 0.2017 .1379122

7. Goniewicz K., Goniewicz M., Pawłowski W. et al. Epidemiology of road traffic accidents in adults. A systematic review. Journal of Education, Health and Sport. 2017;7(7):92-100.
8. Kim J.W., Oh J.K., Byun Y.S. et al. Incidence of avascular necrosis of the femoral head after intramedullary nailing of femoral shaft fractures. A multicenter retrospective analysis of 542 cases. Medicine (Baltimore). 2016 Feb; 95(5): e2728. doi: 10.1097/MD.0000000000002728

9. Larsen P., Elsoe R., Graven-Nielsen T. et al. Decreased muscle strength is associated with impaired long-term functional outcome after intramedullary nailing of femoral shaft fracture. Eur J Trauma Emerg Surg [Internet]. 2015 Dec;41: 673. https://doi.org/10.1007/s00068014-0488-2

This work is a fragment of research work of the Department of Forensic Medicine, Medical Law named after hon. prof. MS Bokarius Kharkiv National Medical University "Forensic substantiation of morpho-clinical criteria for expert assessment of bodily injuries, determination of limitation period and cause of death", state registration number 0115 U000229.

\section{ORCID and contributorship:}

Viacheslav K. Sokol - 0000-0002-8892-1765 A,B,D,F

Vira A. Kolesnichenko - 0000-0003-0503-9732 B,D,E,F

Kostyantin M. Sokol - 0000-0001-6849-579X ${ }^{C, D, F}$

\section{Conflict of interest:}

The Authors declare no conflict of interest.

\author{
CORRESPONDING AUTHOR \\ Viacheslav K. Sokol \\ Kharkiv National Medical University \\ Avenue of Science, 4, Kharkiv, 61022, Ukraine \\ tel: +380675742247 \\ e-mail:sokol_vk@ukr.net
}

Received: 01.03 .2020

Accepted: 05.05 .2020 